medRxiv preprint doi: https://doi.org/10.1101/2021.07.27.21260865; this version posted July 30, 2021. The copyright holder for this preprint

\title{
Distinct pancreatic and neuronal Lung Carcinoid molecular subtypes revealed by
}

\section{integrative omic analysis}

\section{Authors:}

Clara Domingo-Sabugo ${ }^{1}$, Saffron A.G. Willis-Owen ${ }^{1}$, Amit Mandal ${ }^{1}$, Anca Nastase ${ }^{1}$, Sarah Dwyer ${ }^{1}$, Cecilia Brambilla1,2, José Héctor Gálvez³, Qinwei Zhuang33, Sanjay Popatt, ${ }^{4,5}$ Robert Eveleigh³, Markus Munter ${ }^{3}$, Eric Lim', Andrew G. Nicholson ${ }^{1,2}$, Mark Lathrop ${ }^{3}$, William O.C. Cookson ${ }^{1 *}$, Miriam F. Moffatt ${ }^{1 *}$.

\section{Affiliations:}

${ }^{1}$ National Heart and Lung Institute, Imperial College London, London SW3 6LY, UK.

2Department of Histopathology, Royal Brompton and Harefield Hospitals, Guy's and St Thomas' NHS Foundation Trust.

${ }^{3}$ McGill Genome Centre, Montréal, Quebec, H3A 0G1, Canada.

${ }^{4}$ Royal Marsden Hospital NHS Foundation Trust, London and Surrey, UK.

${ }^{5}$ The Institute of Cancer Research, 123 Old Brompton Road, London, SW7 3RP, UK.

${ }^{6}$ Department of Thoracic Surgery, Royal Brompton Hospital, Sydney Street, London SW3 6NP, UK.

"Corresponding authors, these authors contributed equally to this work. 
medRxiv preprint doi: https://doi.org/10.1101/2021.07.27.21260865; this version posted July 30, 2021. The copyright holder for this preprint (which was not certified by peer review) is the author/funder, who has granted medRxiv a license to display the preprint in perpetuity. It is made available under a CC-BY-NC-ND 4.0 International license.

\section{Summary}

Lung Carcinoids (L-CDs) are uncommon low-grade neuroendocrine tumours that are only recently becoming characterised at the molecular level. Notably data on the molecular events that precipitate altered gene expression programmes are very limited. Here we have identified two discrete L-CD subtypes from transcriptomic and whole-genome DNA methylation data, and comprehensively defined their molecular profiles using Whole-Exome Sequencing (WES) and Single Nucleotide Polymorphism (SNP) genotyping. Subtype (Group) 1 features upregulation of neuronal markers (L-CD-NeU) and is characterised by focal spindle cell morphology, peripheral location $(71 \%)$, high mutational load $\left(P=3.4 \times 10^{-4}\right)$, recurrent copy number alterations and is enriched for Atypical Lung Carcinoids. Group 2 (L-CD-PanC) are centrally located and feature upregulation of pancreatic and metabolic pathway genes concordant with promoter hypomethylation of beta cell and genes related to insulin secretion $\left(P<1 \times 10^{-6}\right)$. L-CD-NeU tumours harbour mutations in chromatin remodelling and in SWI/SNF complex members, while L-CDPanC tumours show aflatoxin mutational signatures and significant DNA methylation loss genome-wide, particularly enriched in repetitive elements $\left(P<2.2 \times 10^{-16}\right)$. Our findings provide novel insights into the distinct mechanisms of epigenetic dysregulation in these lung malignancies, potentially opening new avenues for biomarker selection and treatment in L-CD patients. 
medRxiv preprint doi: https://doi.org/10.1101/2021.07.27.21260865; this version posted July 30, 2021. The copyright holder for this preprint (which was not certified by peer review) is the author/funder, who has granted medRxiv a license to display the preprint in perpetuity.

\section{Introduction}

Lung carcinoids (L-CDs) are rare, slow growing neuroendocrine tumours that represent $2 \%$ of all lung cancers ${ }^{1}$ and $30 \%$ of well-differentiated Neuroendocrine Tumours (NETs) throughout the body2 ${ }^{2}$ Diagnosis is currently based on criteria in the WHO Classification of Thoracic Tumours ${ }^{3}$, namely a combination of neuroendocrine morphology, mitotic index and presence or absence of necrosis, supported by immunohistochemistry for neuroendocrine markers.

The latest World Health Organization (WHO) classifies L-CDs as part of the spectrum of neuroendocrine neoplasms (NEN), with typical and atypical L-CDs grouped under the term NETs, and Small Cell Lung Cancer (SCLC) and Large Cell Neuroendocrine Carcinoma (LCNEC) under the term Neuroendocrine Carcinomas (NECs), more in keeping with other organ systems ${ }^{3,4}$. NETs frequently occur in never-smokers, in contrast to NECs. ACs are more aggressive than TCs, with greater likelihood of metastases at presentation and poorer survival. Thus, TCs and ACs are considered low grade and intermediate grade respectively, while LCNECs and SCLC are classified as high-grade. These groupings based on histopathology have been supported by recent genomic and mutational studies that have shown similar genes to be altered across NENs, but differences between NECs and NETs, and within SCLC, LCNEC and NETs themselves, although at different prevalences between NETs, with the lowest number of molecular alterations in L-CDs ${ }^{5-9}$.

Lung carcinoids remain relatively understudied despite their increasing incidence ${ }^{10-16}$. Although many patients with rare NETs can be cured by resection, management of advanced disease remains problematic ${ }^{17}$, and clinically experience no clear pathway of care in their cancer journey, with their tumours difficult to diagnose and treat and patients lacking disease specific support $^{18}$. Disagreement exists over the optimal diagnosis ${ }^{2}$ and there is inter-observer variability in differentiating TCs from $\mathrm{ACs}{ }^{19}$. 
medRxiv preprint doi: https://doi.org/10.1101/2021.07.27.21260865; this version posted July 30, 2021. The copyright holder for this preprint (which was not certified by peer review) is the author/funder, who has granted medRxiv a license to display the preprint in perpetuity. It is made available under a CC-BY-NC-ND 4.0 International license.

To date no lung carcinoid studies have investigated DNA methylation alterations at a genomic scale or have integrated genetic, transcriptomic and clinical data. We therefore describe here a comprehensive characterization of these malignancies at the molecular level. 
medRxiv preprint doi: https://doi.org/10.1101/2021.07.27.21260865; this version posted July 30, 2021. The copyright holder for this preprint (which was not certified by peer review) is the author/funder, who has granted medRxiv a license to display the preprint in perpetuity.

\section{$\underline{\text { Results }}$}

\section{Molecular classification from transcriptomic data}

Unsupervised clustering and Principal Components Analysis (PCA) analysis of RNA sequencing data from 15 LCAR tumours (comprising 3 ACs and 12 TCs) clearly differentiated tumours into two approximately equally sized groups ( $\mathrm{n}=8$ and 7 respectively). These two groups were reproducibly identified using data from the top 500 most variable genes or all sequenced genes $(n$ 25,764) (Supplementary Fig. 1a-b; Supplementary Table 1). Substantial differential expression was present between these groups, with 1,924 transcripts achieving significance at a $1 \%$ False Discovery Rate (FDR) threshold (Fig. 1; Supplementary Data 1). Table 1 lists the top 20 transcripts.

GSEA revealed significantly enriched metabolic pathways and hallmarks of pancreatic beta cells in Group 1 (Supplementary Fig. 2), peaking at regulation of beta cell development (Normalised Enrichment Score [NES] 2.19, $P<0.01$ ). Consistent with these themes, the genes showing the strongest evidence of differential expression, both with relatively raised expression in this group, were TM4SF5 $\left(\log _{2} \mathrm{FC}\right.$ 10.50, adj.P=3.39 $\left.\times 10^{-10}\right)$ and HNF1A $\left(\log _{2} \mathrm{FC}\right.$ 8.33, adj. $\left.P=3.39 \times 10^{-10}\right) . T M 4 S F 5$ is a known tumorigenic factor in several cancer types, including liver, colon, pancreatic and esophageal cancers $^{20-25}$, whilst $H N F 1 A$ encodes a putative master regulator of human pancreatic cancer stem cell properties ${ }^{26}$. The APOBEC1 complementation factor $(A 1 C F)$ showed the highest $\log _{2}$ fold change $\left(\log _{2} \mathrm{FC}\right)$ in expression as compared to Group 2, suggesting that $\mathrm{A} 1 \mathrm{CF}$ protein expression could be used as a molecular marker.

Group 2 showed upregulation of pathways involved in neuronal differentiation, peaking at serotonin neurotransmitter release cycle (NES $-1.79, P=0.004$ ). In line with this pattern, we observed significantly higher expression levels of various neuronal genes in this group (Supplementary Data 1). ASCL1 for example, encodes a neuronal differentiation transcription factor and is a lineage-specific oncogene for high-grade neuroendocrine lung cancer 27,28 , whilst SLIT1, ROBO1 and SRGAP1 all represent members of the cell signalling protein complex slit/robo 
medRxiv preprint doi: https://doi.org/10.1101/2021.07.27.21260865; this version posted July 30, 2021. The copyright holder for this preprint (which was not certified by peer review) is the author/funder, who has granted medRxiv a license to display the preprint in perpetuity. It is made available under a CC-BY-NC-ND 4.0 International license

which is involved in axon guidance and angiogenesis. In addition, FAM3B/PANDER, a pleiotropic secreted cytokine that induces apoptosis in insulin-secreting beta-cells ${ }^{29}$ was highly expressed in Group $2\left(\log _{2} \mathrm{FC} 6.21\right.$, adj. $\left.P=1.76 \times 10^{-5}\right)$. PANDER is expressed ubiquitously, including lung ${ }^{30}$ and some neurons of the brain ${ }^{31}$, and it has recognised roles in invasiveness and tumorigenicity when overexpressed in prostate ${ }^{32}$ and colon ${ }^{33}$ cancers.

On the basis of these features, from this point onwards we refer to Group 1 as LCAR-NeU and Group 2 as LCAR-PanC.

\section{L-CD subtypes are associated with histopathological parameters}

Integration of our findings with clinical parameters showed that LCAR-NeU tumours were characterised by a focal spindle cell morphology (two-sided Fisher's exact test: estimate 17.50 [95\% CI 1.24, 227.8], $P=0.041$ ) and peripheral location (two-sided Fisher's exact test: estimate - 0 [95\% CI 0, 0.46], P=0.007) (Figs. 2a and 2b) and included every tumour of an Atypical Lung Carcinoid histology ( $n$ 3). LCAR-PanCs on the other hand, were all located centrally. Whilst LCAR-NeU patients exhibited a trend towards an older age, this difference was not statistically significant (Welch's $t$-test: $\mathrm{t}$-2.01; estimate PanC=53.63, estimate $\mathrm{NeU}=68.86$ [95\% CI -32.06, 1.59]; df 10.5; $P=0.071$ ). No significant association was seen with survival, smoking history, sex, presence of emphysema, nodal stage and either lymph or vascular invasion.

\section{Mutational signatures of L-CD subtypes}

We sought to investigate the molecular features associated with these contrasting expression programmes by analysing the spectrum of somatic base substitutions and their trinucleotide context. The mutational load was significantly higher in LCAR-NeU with 45.83 mutations on average, compared with 27.87 for LCAR-PanC (two-sided $t$-test: $t$-4.66; estimate PanC $=27.87$, estimate $\mathrm{NeU}=45.83$ [95\% CI -26.36, -9.56]; df 12; $\left.P=5.53 \times 10^{-4}\right)$ (Supplementary Fig. 3a). 
medRxiv preprint doi: https://doi.org/10.1101/2021.07.27.21260865; this version posted July 30, 2021. The copyright holder for this preprint (which was not certified by peer review) is the author/funder, who has granted medRxiv a license to display the preprint in perpetuity. It is made available under a CC-BY-NC-ND 4.0 International license

This is consistent with a higher mean number of mutations detected in ACs, and tumours from this histology all falling in the LCAR-NeU molecular group.

A different spectrum of COSMIC Mutational Signatures (CMS) was consistently observed between the two LCAR groups; $50 \%$ of LCAR-PanC samples possessed an aflatoxin exposure signature. This is consistent with our differential gene expression data, in which several genes (GGT5, CYP34A, CYP3A5 and DPEP1) participating in aflatoxin activation and detoxification were expressed at significantly higher levels in PanC tumours.

On the other hand, LCAR-NeU samples variably showed a CMS 5 signature (57\%), which is found in most cancer samples, and/or a CMS 8 signature (43\%), which is associated with double strand break repair by homologous recombination. A summary of the mutational signatures is given in Supplementary Figure 4a-b.

Since most observed signatures were of unknown aetiology, we identified the de novo mutational signatures and related these to catalogued (COSMIC) signatures ${ }^{34}$. Analysis with a cophenetic correlation metric confirmed a consistent presence of different spectra of mutational signatures in the two groups. LCAR-PanC showed an aflatoxin signature (CSM 24; cosine similarity of 0.603 ), while LCAR-NeU showed spontaneous deamination of 5-methylcytosine (CSM 1; cosine similarity of 0.801 ). Both groups were found to share a mutational signature associated with defective DNA mismatch repair (CSM 20; cosine similarities of 0.399 in PanC and 0.642 in NeU) (Supplementary Fig. 5). These data confirm a biological distinction between the two observed LCAR subtypes.

\section{Mutations and Copy Number Alterations (CNAs) in L-CD subtypes}

The most frequently mutated genes in $\mathrm{L}-\mathrm{CD}-\mathrm{NeU}$ were components of the cytoskeleton (57\%), including ITGA1, ITGA2, PLEC and TPJ1, and histone covalent modifiers (43\%) (JMJD1C, KDM1B and KDM4E) (Fig. 3). By contrast, L-CD-PanC tumours showed mutations in ARID1A and 
medRxiv preprint doi: https://doi.org/10.1101/2021.07.27.21260865; this version posted July 30, 2021. The copyright holder for this preprint (which was not certified by peer review) is the author/funder, who has granted medRxiv a license to display the preprint in perpetuity. It is made available under a CC-BY-NC-ND 4.0 International license .

ARID5B (25\%), both members of the SWI/SNF complex; and the Notch signalling genes PLXND1 and/or WWC1 (25\%). Notch signalling controls cell fate decisions and has previously been found to be activated in neuroendocrine cells undergoing reprogramming after injury ${ }^{35}$.

No significant difference in copy number burden $(\mathrm{CNB})$ could be detected between the two L-CD classifications. Just 4.8 and $5.5 \%$ of the genome showed evidence of CNB in L-CD-NeU and L-CD-PanC respectively (inter-sample range L-CD-NeU: $0.3 \%-14.5 \%$; L-CD-PanC: $0.3 \%$ 19.3\%). These values lie within the range previously defined in healthy human populations ${ }^{36}$.

Individual CNAs were found in genes related to the innate immune system and neutrophil degranulation, and included deletions affecting C1orf127 (1p36.22), TXK and TEC (4q12), NDUFS2 (1q23.3), KIF20B (10q23), INMT, ROCK1 and zinc finger proteins (ZNF180, ZNF846, ZNF283, ZNF404). One significant amplification was found in SCYP2, a major component of the synaptonemal complex during meiotic division. A summary of the genes harbouring mutations and CNAs is given in Figure 4 with information regarding genes in significant cytobands and the percentages for CNAs in each subtype are detailed in Supplementary Table 2.

Similar to mutations, L-CD-NeU showed higher frequencies of CNAs, with $71.43 \%$ of tumours harbouring KIF20B deletions, a kinesin involved in neuron polarization ${ }^{37}$. In contrast with earlier studies ${ }^{38}$, we did not detect any significant loss in RB1, TP53 and MEN1 or any significant gains in TERT, SDHA or RICTOR.

\section{Focal and widespread DNA methylation changes distinguish L-CD subtypes}

Aberrant DNA methylation is a common feature of cancer and provides a mechanism of gene expression dysregulation. Here we applied whole genome bisulfite sequencing (WGBS) to generate a snapshot of the DNA methylation profile in tumour and matched histologically normal tissue. Mirroring our observations from transcriptomic data, PCA of genome-wide DNA methylation data differentiated L-CD-NeU from L-CD-PanC tumours (Fig. 4a). We identified 4,304 
medRxiv preprint doi: https://doi.org/10.1101/2021.07.27.21260865; this version posted July 30, 2021. The copyright holder for this preprint (which was not certified by peer review) is the author/funder, who has granted medRxiv a license to display the preprint in perpetuity. It is made available under a CC-BY-NC-ND 4.0 International license.

significant Differentially Methylated Regions (DMRs) distinguishing these L-CD groups (Supplementary Data 2), and consistent with gene expression data, we identified promoters of genes expressed in beta cells and related to insulin secretion as hypomethylated in the L-CD-PanC group (Fig. 5). Other hypomethylated genes included SMAD7, NRG1 and PMS1. On the other hand, L-CD-NeU tumours showed hypomethylation of the PI3K/AKT/mTOR signalling pathway, a pathway known to be involved in pluripotency and cell fate determination, and HOXB2 and HOXB developmental genes were also found to be hypomethylated. $H O X$ genes are major transcriptional regulators. They have key roles in development, and frequent epigenetic and/or transcriptional deregulation in cancer ${ }^{39,40}$.

Nevertheless, most DMRs mapped to intergenic and intronic regions (Supplementary Table 3). We therefore sought to investigate the properties of DNA methylation alterations in the non-coding genome of the two L-CD groups. PCA analysis of different genomic regions' DNA methylation levels revealed that repeated elements explained most of the variance $(26.89 \%)$ and alone distinguished L-CD-NeU from L-CD-PanC (Fig. 4b).

Reactivation of transposable elements (TE) through epigenetic mechanisms is an established feature of some cancers with roles in tumour immunity ${ }^{41}$. We found here a significant enrichment of TEs in hypomethylated DMRs (relative enrichment $=1.31,95 \%$ CI 1.16-1.48, $\left.P=8.03 \times 10^{-06}\right)$. Specifically, DMRs enriched in TEs with a 30\% fraction overlap were significantly lowly methylated (two-sided Wilcoxon matched-pairs signed rank test: V 446264, estimate 0.03 [95\% CI -0.04, -0.03], $P<2.2 \times 10^{-16}$ ) in PanC tumours (Supplementary Fig. 6). Repeat elements and non-genic CpG sites are known to lose methylation during aging ${ }^{42}$, nevertheless, we found no significant difference in age between LCAR subtypes. 
medRxiv preprint doi: https://doi.org/10.1101/2021.07.27.21260865; this version posted July 30, 2021. The copyright holder for this preprint (which was not certified by peer review) is the author/funder, who has granted medRxiv a license to display the preprint in perpetuity. It is made available under a CC-BY-NC-ND 4.0 International license.

\section{Discussion}

In this study we have identified two distinct molecular subtypes of L-CDs from RNAsequencing data; L-CD-NeU and L-CD-PanC, and characterised their molecular profiles using WES, SNP genotyping and WGBS. We have shown that these two groups differ significantly in their transcriptional, mutational and epigenetic profiles, as well as their physical characteristics.

Differential analysis of gene expression data showed upregulation of metabolic pathways and hallmarks of pancreatic beta cells in PanC tumours, whereas pathways related to the neuronal system, neurotransmitter synthesis and release were found enriched in NeU tumours. Differential expression between these two groups was most marked with TM4SF5, notable since TM4SF5targeted monoclonal antibody and peptide vaccination has previously established preventive and/or therapeutic effects in hepatocellular carcinoma, colon cancer and pancreatic cancer models ${ }^{25}$. On the basis of these data, assessment of anti-hTM4SF5 antibody treatment efficacy in TM4SF5-expressing PanC L-CDs may be warranted.

In our transcriptomic data, $A 1 C F$ showed the highest $\log _{2}$ fold-change expression between the two L-CD groups suggesting that A1CF protein expression may have utility as a molecular marker for anti-hTM4SF5 antibody therapy. Furthermore, we show that the NeU L-CD classification is significantly associated with a focal spindle cell morphology and peripheral tumour location, meaning that these physical features may provide a minimally invasive, accessible proxy, in agreement with the distinct characteristics of central and peripheral carcinoids reported by George et $\mathrm{al}^{43}$. Additionally, FAM3B/PANDER expression has been detected at the protein level and its inhibition has shown antitumour effects in vitro in prostate and several human cancer lines ${ }^{30}$, suggesting therapeutic potential and a marker for the differential diagnosis of L-CD subtypes in combination with TM4SF5 and A1CF protein expression.

Molecular profiling of L-CDs have previously shown chromatin remodelling genes, such as MEN1, ARID1A, PSIP1, KMT2C and KMT2A, to be recurrently mutated in L-CDs while TP53, 
medRxiv preprint doi: https://doi.org/10.1101/2021.07.27.21260865; this version posted July 30, 2021. The copyright holder for this preprint (which was not certified by peer review) is the author/funder, who has granted medRxiv a license to display the preprint in perpetuity. It is made available under a CC-BY-NC-ND 4.0 International license .

RB1 and STK11 mutations have been found frequently altered in non-carcinoid NETs ${ }^{44}$. Other studies have emphasized the distinction between TCs and ACs, and molecular events distinguishing these subtypes are reported to affect the genes MEN1, TP53, KMT2C, TERT, SDHA, RICTOR and $R B 1^{6}$. In our study we did not detect any mutation or CNA in any of these genes, in contrast with earlier studies ${ }^{6,28}$.

L-CD-NeU showed a higher tumour mutational load affecting cytoskeletal genes and histone covalent modifiers. Conversely, L-CD-PanC tumours showed a lower mutational load, mostly affecting members of the SWI/SNF complex and Notch signalling pathways. L-CD-NeU tumours also showed more recurrent CNAs than L-CD-PanCs. Although L-CD-NeUs encompassed all the ACs, most members of this group had typical histology, highlighting the potential importance of molecular screening to help in the therapy decision process.

To gain insights into the biological mechanisms involved in L-CD carcinogenesis, we looked for the most frequent combinations of somatic mutations and identified a combination of known and de novo mutational signatures. Known mutational signatures from the COSMIC database (https://cancer.sanger.ac.uk/signatures/) revealed a mixed repertoire of signatures that have been found in other cancer types. Consequently we identified de novo signatures and compared them with known catalogued COSMIC signatures. Both approaches linked an aflatoxin signature with L-CD-PanC, whereas signatures previously found in all cancer types were identified in the L-CD-NeU group.

Aflatoxin B1 (AFB1) is a potent genotoxin produced by species of the Aspergillus fungus. It can bind to double stranded $\mathrm{DNA}^{45}$ and induce hepatocellular carcinoma leaving a $\mathrm{C} \rightarrow \mathrm{A}$ mutational signature ${ }^{46,47,48}$. Pancreatic tumours have previously showed dominance of this signature potentially due to the mutational properties of AFB1-DNA adducts ${ }^{49,50,51,52}$. Extrahepatic tissues, such as the nasal olfactory and respiratory mucosa, and mucosa of the trachea and oesophagus have a high capacity to activate AFB1 which when inhaled may cause lung cancer ${ }^{53,54}$. 
medRxiv preprint doi: https://doi.org/10.1101/2021.07.27.21260865; this version posted July 30, 2021. The copyright holder for this preprint (which was not certified by peer review) is the author/funder, who has granted medRxiv a license to display the preprint in perpetuity. It is made available under a CC-BY-NC-ND 4.0 International license.

Here we observed predominance of $C \rightarrow A$ mutations in the L-CD-PanC group (Supplementary Fig. 3b). High levels of AFB1 can be present in respiratory grain-dust particles ${ }^{55,56}$, and as such could potentially contribute to L-CD-PanC carcinogenesis. Controlled experiments designed to detect and define any role of aflatoxin in L-CD-PanC pathogenesis should be a priority for future investigation.

The mutational landscapes of L-CDs alone could not explain the transcriptomic differences detected and so we analysed their DNA methylomes by using WGBS data. We identified DMRs in promoters of pancreatic beta cells and genes related to insulin secretion in L-CD-PanCs, as well as mismatch repair genes, pinpointing DNA methylation changes as a key event in this cancer group.

TE-enriched regions showed significant hypomethylation in L-CD-PanCs and alone were sufficient to differentiate from L-CD-Neu tumours by PCA analysis. This suggests that epigenetic dysregulation in the non-coding genome may be a major contributor to the PanC subtype. Significantly higher expression levels of $A 1 C F$ in L-CD-PanC tumour genomes may contribute to this generalised hypomethylation. A1CF serves as a docking site to recruit APOBEC1 deaminase, which has a role in active DNA demethylation followed by T:G mismatch repair ${ }^{57,58}$. Altogether these findings highlight the value of whole-genome data to better understand and refine the molecular alterations in these malignancies.

We recognise a number of limitations of our study. The relative rarity of L-CD tumours and access to fresh frozen tissue has meant that our sample size is fairly small. Histopathological analyses with the markers we have identified could validate the observed classifications and should be a priority for future studies to enable translation into a clinical setting.

The distinct clinical phenotypes associated with these molecular subtypes suggest novel biomarkers for patient stratification. Our findings could be used to refine and complement the 
medRxiv preprint doi: https://doi.org/10.1101/2021.07.27.21260865; this version posted July 30, 2021. The copyright holder for this preprint (which was not certified by peer review) is the author/funder, who has granted medRxiv a license to display the preprint in perpetuity. It is made available under a CC-BY-NC-ND 4.0 International license.

current WHO classification of lung carcinoids and will stimulate further investigation to improve the cancer journey of patients with L-CD 
medRxiv preprint doi: https://doi.org/10.1101/2021.07.27.21260865; this version posted July 30, 2021. The copyright holder for this preprint (which was not certified by peer review) is the author/funder, who has granted medRxiv a license to display the preprint in perpetuity. It is made available under a CC-BY-NC-ND 4.0 International license.

\section{$\underline{\text { References }}$}

1. Rekhtman, N. Neuroendocrine tumors of the lung. Arch. Pathol. Lab. Med. 134, 1628-1638 (2010).

2. Caplin, M. E. et al. Pulmonary neuroendocrine (carcinoid) tumors: European Neuroendocrine Tumor Society expert consensus and recommendations for best practice for typical and atypical pulmonary carcinoids. Ann. Oncol. 26, 1604-1620 (2015).

3. Tumours, W. C. of. Thoracic Tumours: WHO Classification of Tumours. (2021).

4. Rindi, G. et al. A common classification framework for neuroendocrine neoplasms: an International Agency for Research on Cancer (IARC) and World Health Organization (WHO) expert consensus proposal. Mod. Pathol. 31, 1770-1786 (2018).

5. Ullmann, R. et al. Unbalanced chromosomal aberrations in neuroendocrine lung tumors as detected by comparative genomic hybridization. Hum. Pathol. 29, 1145-1149 (1998).

6. Simbolo, M. et al. Lung neuroendocrine tumours: deep sequencing of the four World Health Organization histotypes reveals chromatin-remodelling genes as major players and a prognostic role for TERT, RB1, MEN1 and KMT2D. J. Pathol. 241, 488-500 (2017).

7. Derks, J. L. et al. New Insights into the Molecular Characteristics of Pulmonary Carcinoids and Large Cell Neuroendocrine Carcinomas, and the Impact on Their Clinical Management. J. Thorac. Oncol. Off. Publ. Int. Assoc. Study Lung Cancer 13, 752-766 (2018).

8. Rekhtman, N. et al. Next-Generation Sequencing of Pulmonary Large Cell Neuroendocrine Carcinoma Reveals Small Cell Carcinoma-like and Non-Small Cell Carcinoma-like Subsets. Clin. cancer Res. an Off. J. Am. Assoc. Cancer Res. 22, 3618-3629 (2016).

9. Alcala, N. et al. Integrative and comparative genomic analyses identify clinically relevant pulmonary carcinoid groups and unveil the supra-carcinoids. Nat. Commun. 10, (2019).

10. Randimbison, L., Rindi, G. \& Vecchia, C. La. Epidemiology of carcinoid neoplasms in Vaud, Switzerland, 1974-97. Br. J. Cancer 83, 952-955 (2000).

11. Skuladottir, H., Hirsch, F. R., Hansen, H. H. \& Olsen, J. H. E-74. Pulmonary neuroendocrine tumors: Incidence and prognosis of histological subtypes. A population-based study in 
medRxiv preprint doi: https://doi.org/10.1101/2021.07.27.21260865; this version posted July 30, 2021. The copyright holder for this preprint (which was not certified by peer review) is the author/funder, who has granted medRxiv a license to display the preprint in perpetuity. It is made available under a CC-BY-NC-ND 4.0 International license.

Denmark. Lung Cancer 41, S92 (2003).

12. Govindan, R. et al. Changing epidemiology of small-cell lung cancer in the United States over the last 30 years: Analysis of the surveillance, epidemiologic, and end results database. J. Clin. Oncol. 24, 4539-4544 (2006).

13. Yao, J. C. et al. One hundred years after 'carcinoid': Epidemiology of and prognostic factors for neuroendocrine tumors in 35,825 cases in the United States. J. Clin. Oncol. 26, 3063-3072 (2008).

14. Chang, J. S. \& Chen, L. The epidemiologic trends of neuroendocrine tumors in Taiwan: an updated analysis of a nation-wide population-based study. 1-16 (2020) doi:10.21203/rs.3.rs69891/v1.

15. Hallet, J. et al. Exploring the rising incidence of neuroendocrine tumors: A population-based analysis of epidemiology, metastatic presentation, and outcomes. Cancer 121, 589-597 (2015).

16. Ellis, L., Shale, M. J. \& Coleman, M. P. Carcinoid tumors of the gastrointestinal tract: trends in incidence in England since 1971. Am. J. Gastroenterol. 105, 2563-2569 (2010).

17. Kane, A. et al. Predictors of survival in 211 patients with stage IV pulmonary and gastroenteropancreatic MIBG-Positive neuroendocrine tumors treated with 131I-MIBG. J. Nucl. Med. 59, 1708-1713 (2018).

18. Feinberg, Y., Law, C., Singh, S. \& Wright, F. C. Patient experiences of having a neuroendocrine tumour: A qualitative study. Eur. J. Oncol. Nurs. 17, 541-545 (2013).

19. Swarts, D. R. A. et al. Interobserver variability for the WHO classification of pulmonary carcinoids. Am. J. Surg. Pathol. 38, 1429-1436 (2014).

20. Müller-Pillasch, F. et al. Identification of a new tumour-associated antigen TM4SF5 and its expression in human cancer. Gene 208, 25-30 (1998).

21. Lee, S. A. et al. Tetraspanin TM4SF5 mediates loss of contact inhibition through epithelialmesenchymal transition in human hepatocarcinoma. J. Clin. Invest. 118, 1354-1366 (2008).

22. Kwon, S. et al. Prophylactic effect of a peptide vaccine targeting TM4SF5 against colon cancer in a mouse model. Biochem. Biophys. Res. Commun. 435, 134-139 (2013). 
medRxiv preprint doi: https://doi.org/10.1101/2021.07.27.21260865; this version posted July 30, 2021. The copyright holder for this preprint (which was not certified by peer review) is the author/funder, who has granted medRxiv a license to display the preprint in perpetuity. It is made available under a CC-BY-NC-ND 4.0 International license.

23. Wu, Y. B. et al. A high level of TM4SF5 is associated with human esophageal cancer progression and poor patient survival. Dig. Dis. Sci. 58, 2623-2633 (2013).

24. Lee, J. W. TM4SF5-mediated protein-protein networks and tumorigenic roles. BMB Rep. 47, 483487 (2014).

25. Park, S., Kim, D., Park, J. A., Kwon, H. J. \& Lee, Y. Targeting TM4SF5 with anti-TM4SF5 monoclonal antibody suppresses the growth and motility of human pancreatic cancer cells. Oncol. Lett. 19, 641-650 (2020).

26. Abel, E. V. et al. HNF1A is a novel oncogene that regulates human pancreatic cancer stem cell properties. Elife 7, 1-35 (2018).

27. Richards et al. ASCL1 and NEUROD1 reveal heterogeneity in pulmonary neuroendocrine tumors and regulate distinct genetic programs. Physiol. Behav. 176, 139-148 (2018).

28. Laddha, S. V. et al. Integrative genomic characterization identifies molecular subtypes of lung carcinoids. Cancer Res. 79, 4339-4347 (2019).

29. Cao, X. et al. Pancreatic-derived factor (FAM3B), a novel islet cytokine, induces apoptosis of insulin-secreting $\beta$-cells. Diabetes 52, 2296-2303 (2003).

30. Mou, H. et al. Knockdown of FAM3B triggers cell apoptosis through p53-dependent pathway. Int. J. Biochem. Cell Biol. 45, 684-691 (2013).

31. Zhu, Y. et al. Cloning, expression, and initial characterization of a novel cytokine-like gene family. Genomics 80, 144-150 (2002).

32. Maciel-Silva, P. et al. FAM3B/PANDER inhibits cell death and increases prostate tumor growth by modulating the expression of Bcl-2 and Bcl-XL cell survival genes. BMC Cancer 18, 1-15 (2018).

33. Li, Z. et al. A non-secretory form of FAM3B promotes invasion and metastasis of human colon cancer cells by upregulating Slug expression. Cancer Lett. 328, 278-284 (2013).

34. Alexandrov, L. B., Nik-Zainal, S., Wedge, D. C., Campbell, P. J. \& Stratton, M. R. Deciphering Signatures of Mutational Processes Operative in Human Cancer. Cell Rep. 3, 246-259 (2013). 
medRxiv preprint doi: https://doi.org/10.1101/2021.07.27.21260865; this version posted July 30, 2021. The copyright holder for this preprint (which was not certified by peer review) is the author/funder, who has granted medRxiv a license to display the preprint in perpetuity. It is made available under a CC-BY-NC-ND 4.0 International license.

35. Ouadah, Y. et al. Rare Pulmonary Neuroendocrine Cells Are Stem Cells Regulated by Rb, p53, and Notch. Cell 179, 403-416.e23 (2019).

36. Zarrei, M., MacDonald, J. R., Merico, D. \& Scherer, S. W. A copy number variation map of the human genome. Nat. Rev. Genet. 16, 172-183 (2015).

37. McNeely, K. C. et al. Mutation of Kinesin-6 Kif20b causes defects in cortical neuron polarization and morphogenesis. Neural Dev. 12, 1-18 (2017).

38. Simbolo, M. et al. Lung neuroendocrine tumours: deep sequencing of the four World Health Organization histotypes reveals chromatin-remodelling genes as major players and a prognostic role for TERT, RB1, MEN1 and KMT2D. J. Pathol. 241, 488-500 (2017).

39. Golpon, H. A. et al. HOX Genes in Human Lung. Am. J. Pathol. 158, 955-966 (2001).

40. Shah, N. \& Sukumar, S. The Hox genes and their roles in oncogenesis. Nat. Rev. Cancer 10, 361$371(2010)$

41. Kong, Y.et al. Transposable element expression in tumors is associated with immune infiltration and increased antigenicity. Nat. Commun. 10, (2019).

42. Bollati, V. et al. Decline in Genomic DNA Methylation through Aging in a Cohort of Elderly Subjects. October 130, 234-239 (2010).

43. Papaxoinis, G., Lamarca, A., Quinn, A. M., Mansoor, W. \& Nonaka, D. Clinical and Pathologic Characteristics of Pulmonary Carcinoid Tumors in Central and Peripheral Locations. Endocr. Pathol. 29, 259-268 (2018).

44. Asiedu, M. K. et al. Pathways impacted by genomic alterations in pulmonary carcinoid tumors. Clin. Cancer Res. 24, 1691-1704 (2018).

45. Yu, F.-L., Bender, W. \& Geronimo, I. H. Base and sequence specificities of aflatoxin B1 binding to single- and double-stranded DNAs. Carcinogenesis 11, 475-478 (1990).

46. Bannasch, P. et al. Synergistic Hepatocarcinogenic Effect of Hepadnaviral Infection and Dietary Aflatoxin B1 in Woodchucks. Cancer Res. 55, 3318-3330 (1995).

47. Chawanthayatham, S. et al. Mutational spectra of aflatoxin B1 in vivo establish biomarkers of 
medRxiv preprint doi: https://doi.org/10.1101/2021.07.27.21260865; this version posted July 30, 2021. The copyright holder for this preprint (which was not certified by peer review) is the author/funder, who has granted medRxiv a license to display the preprint in perpetuity. It is made available under a CC-BY-NC-ND 4.0 International license.

exposure for human hepatocellular carcinoma. Proc. Natl. Acad. Sci. U. S. A. 114, E3101-E3109 (2017).

48. Schulze, K. et al. Exome sequencing of hepatocellular carcinomas identifies new mutational signatures and potential therapeutic targets. Nat. Genet. 47, 505-511 (2015).

49. Smela, M. E. et al. The aflatoxin B1 formamidopyrimidine adduct plays a major role in causing the types of mutations observed in human hepatocellular carcinoma. Proc. Natl. Acad. Sci. U. S. A. 99, 6655-6660 (2002).

50. Woo, L. L. et al. Aflatoxin B1-DNA adduct formation and mutagenicity in livers of neonatal male and female B6C3F1 mice. Toxicol. Sci. 122, 38-44 (2011).

51. Alekseyev, Y. O., Hamm, M. L. \& Essigmann, J. M. Aflatoxin B1 formamidopyrimidine adducts are preferentially repaired by the nucleotide excision repair pathway in vivo. Carcinogenesis 25, 1045-1051 (2004).

52. Alexandrov, L. B. et al. Signatures of mutational processes in human cancer. Nature 500, 415-421 (2013).

53. Coulombe, R., Eaton, D. \& Groopman, J. Nonhepatic Disposition and Effects of Aflatoxin B1. in (1993).

54. Gursoy, N. et al. Changes in spontaneous contractions of rat ileum by aflatoxin in vitro. Food Chem. Toxicol. 46, 2124-2127 (2008).

55. Sorenson, W. G., Simpson, J. P., III, M. J. P., Thedell, T. D. \& Olenchock, S. A. Aflatoxin in respirable corn dust particles. J. Toxicol. Environ. Health 7, 669-672 (1981).

56. Burg, W. R. \& Shotwell, O. L. Aflatoxin Levels in Airborne Dust Generated from Contaminated Corn During Harvest and at an Elevator in 1980. J. Assoc. Off. Anal. Chem. 67, 309-312 (1984).

57. Ramiro, A. R. \& Barreto, V. M. Activation-induced cytidine deaminase and active DNA demethylation. Trends Biochem. Sci. 40, 172-181 (2015).

58. Jonathan Posner and Bradley S. Peterson, J. A. R. Hydroxylation of 5-methylcytosine by TET1 promotes active DNA demethylation in the adult brain. Bone 23, 1-7 (2008). 
medRxiv preprint doi: https://doi.org/10.1101/2021.07.27.21260865; this version posted July 30, 2021. The copyright holder for this preprint

(which was not certified by peer review) is the author/funder, who has granted medRxiv a license to display the preprint in perpetuity.

It is made available under a CC-BY-NC-ND 4.0 International license.

59. Hoang, L. T. et al. Metabolomic, transcriptomic and genetic integrative analysis reveals important roles of adenosine diphosphate in haemostasis and platelet activation in non-smallcell lung cancer. Mol. Oncol. 13, 2406-2421 (2019).

60. Liberzon, A. et al. The Molecular Signatures Database (MSigDB) hallmark gene set collection. 1, $417-425$ (2016).

61. Bourgey, M. et al. GenPipes: An open-source framework for distributed and scalable genomic analyses. Gigascience 8, 1-11 (2019). 
medRxiv preprint doi: https://doi.org/10.1101/2021.07.27.21260865; this version posted July 30, 2021. The copyright holder for this preprint (which was not certified by peer review) is the author/funder, who has granted medRxiv a license to display the preprint in perpetuity.

\section{Figures}

Figure 1: Heatmap of the significantly differentially expressed (DE) genes (adj.P<0.01) between

\section{L-CD subtypes.}

Group 1: L-CD-NeU

Group 2: L-CD-PanC
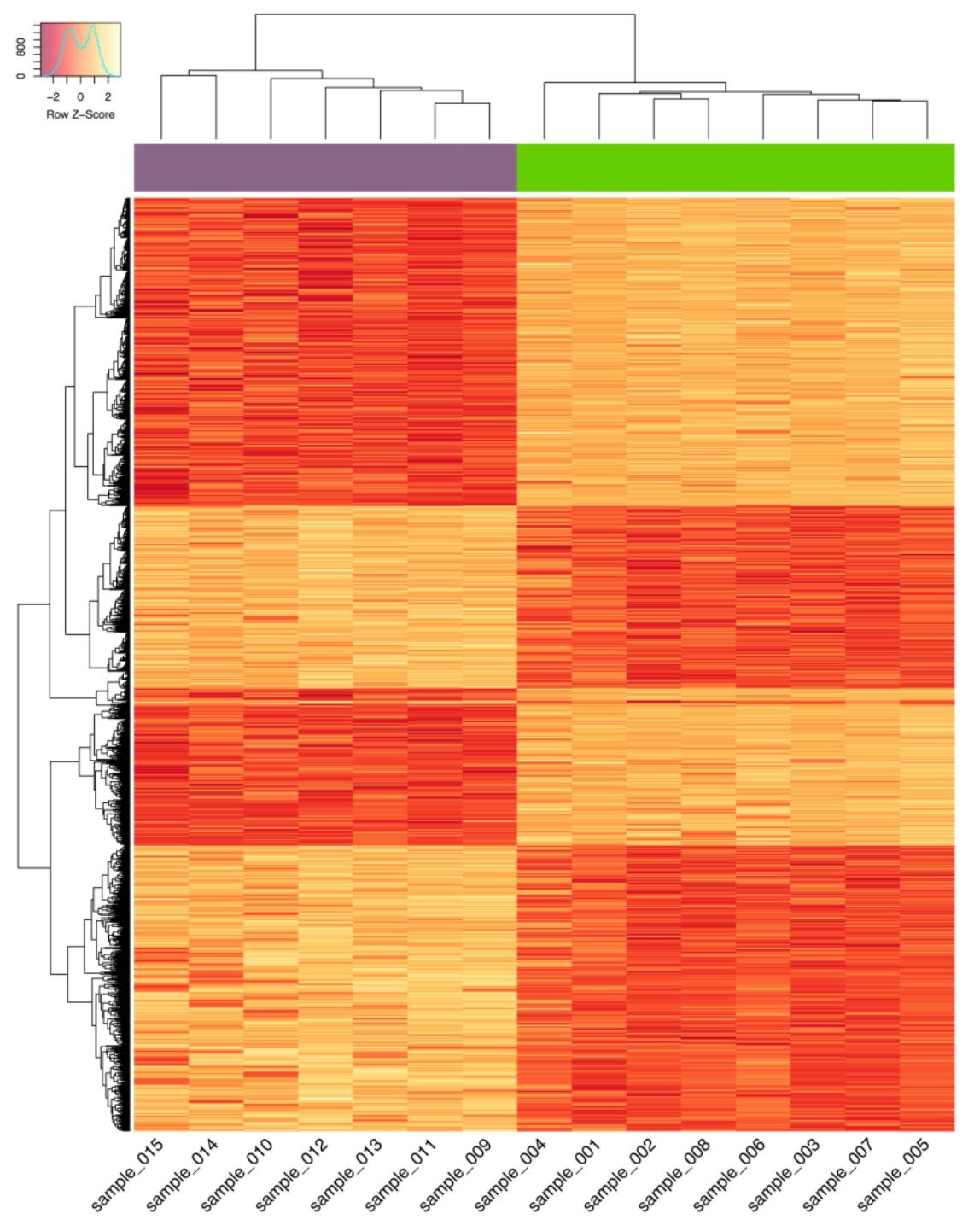

Figure 1: Heatmap of the significantly differentially expressed (DE) genes ( adj.P<0.01) between

L-CD subtypes. Figure displays heat map and dendrograms with hierarchical clustering

of 15 lung carcinoids (on the $\mathrm{X}$ axis) and genes (on the $\mathrm{Y}$ axis) that were significantly

differentially expressed. Top bar indicates lung carcinoid group membership. 
medRxiv preprint doi: https://doi.org/10.1101/2021.07.27.21260865; this version posted July 30, 2021. The copyright holder for this preprint (which was not certified by peer review) is the author/funder, who has granted medRxiv a license to display the preprint in perpetuity. It is made available under a CC-BY-NC-ND 4.0 International license .

Figure 2: L-CD molecular groups have distinct histological characteristics.

a

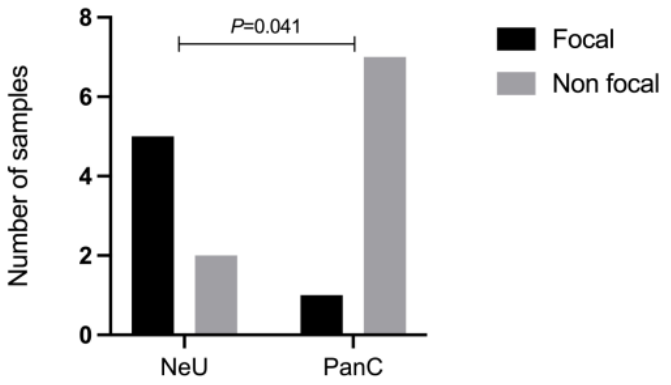

b

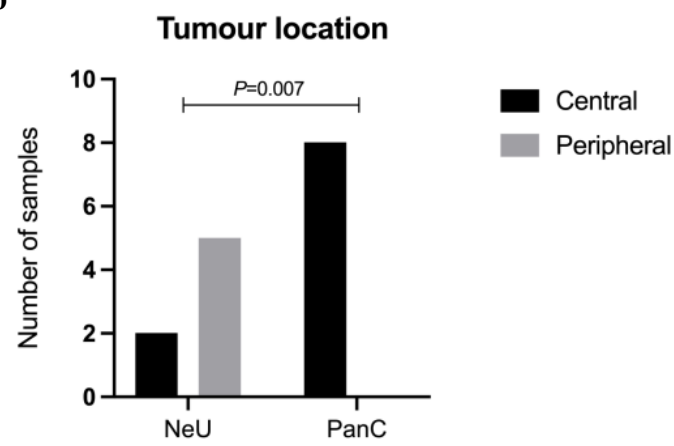

Figure 2: L-CD molecular groups have distinct histological characteristics. a) Focal spindle cell morphology in L-CD-NeU versus L-CD-PanC. b) Central or affecting the main lobar broncos versus peripheral tumour location between $\mathrm{L}-\mathrm{CD}-\mathrm{NeU}$ and $\mathrm{L}-\mathrm{CD}$-PanC. $P$-values are for twosided Fisher's statistical tests. 
medRxiv preprint doi: https://doi.org/10.1101/2021.07.27.21260865; this version posted July 30, 2021. The copyright holder for this preprint (which was not certified by peer review) is the author/funder, who has granted medRxiv a license to display the preprint in perpetuity.

Figure 3: Mutational landscape of -LCD molecular groups.

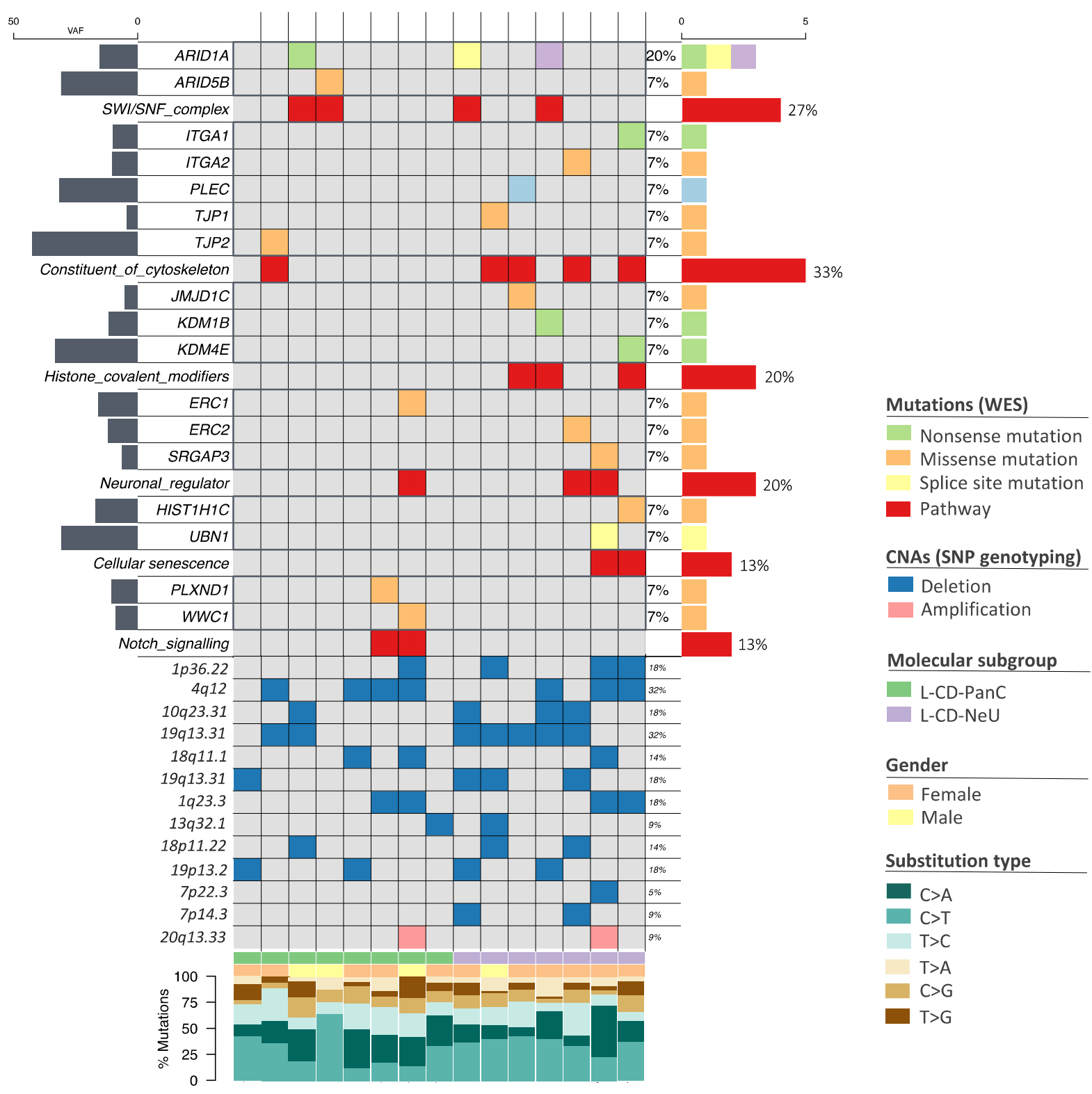

Figure 3: Mutational landscape of -LCD molecular groups. Oncoplot of the most recurrent mutations, InDels and significant copy number alterations (CNAs) in LCAR-NeUs $(n=7)$ and LCAR-PanCs $(n=8)$. Abbreviations: VAF (Variant Allele Frequency); WES (WholeExome Sequencing). 
medRxiv preprint doi: https://doi.org/10.1101/2021.07.27.21260865; this version posted July 30, 2021. The copyright holder for this preprint (which was not certified by peer review) is the author/funder, who has granted medRxiv a license to display the preprint in perpetuity. It is made available under a CC-BY-NC-ND 4.0 International license.

Figure 4: Principal components analysis of whole genome (a) and repeat element (b) CpG DNA methylation data differentiates L-CD molecular groups.

a

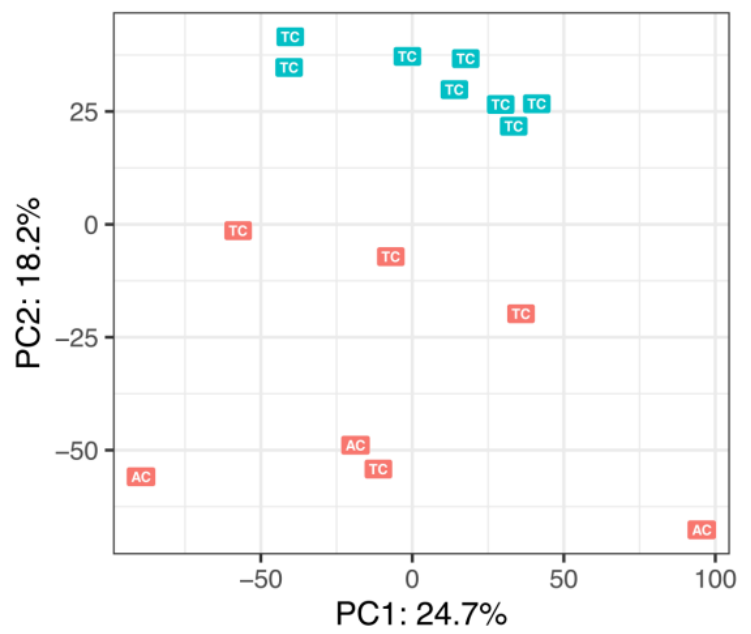

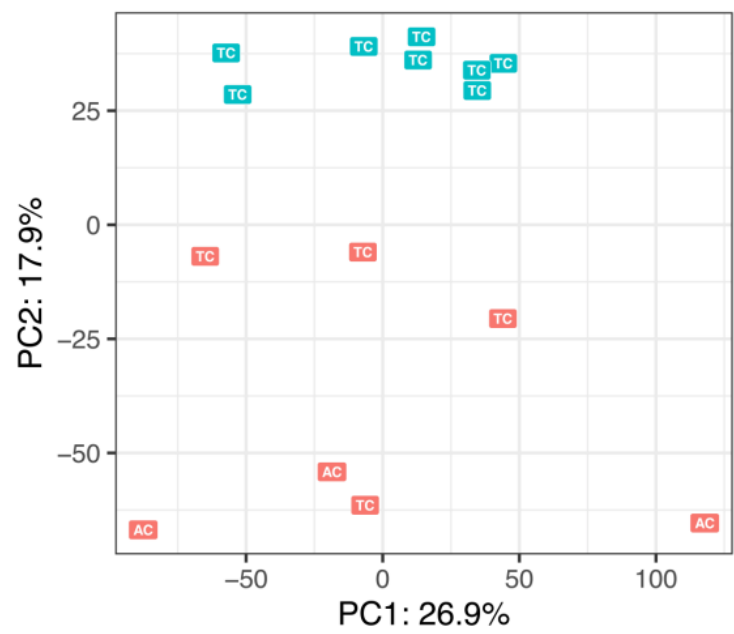

Figure 4: Principal components analysis of whole genome (a) and repeat element (b) CpG DNA methylation data differentiates L-CD molecular groups. Figure shows principal components analysis of WGBS data, a: whole genome, b: repeat elements only. NeU tumours are shown in red, PanC tumours are shown in blue. Histology is shown as TC and AC for Typical Carcinoid and Atypical Carcinoid, respectively. 
medRxiv preprint doi: https://doi.org/10.1101/2021.07.27.21260865; this version posted July 30, 2021. The copyright holder for this preprint (which was not certified by peer review) is the author/funder, who has granted medRxiv a license to display the preprint in perpetuity. It is made available under a CC-BY-NC-ND 4.0 International license.

Figure 5: Genes with promoters showing significant differential methylation between L-CD molecular groups.

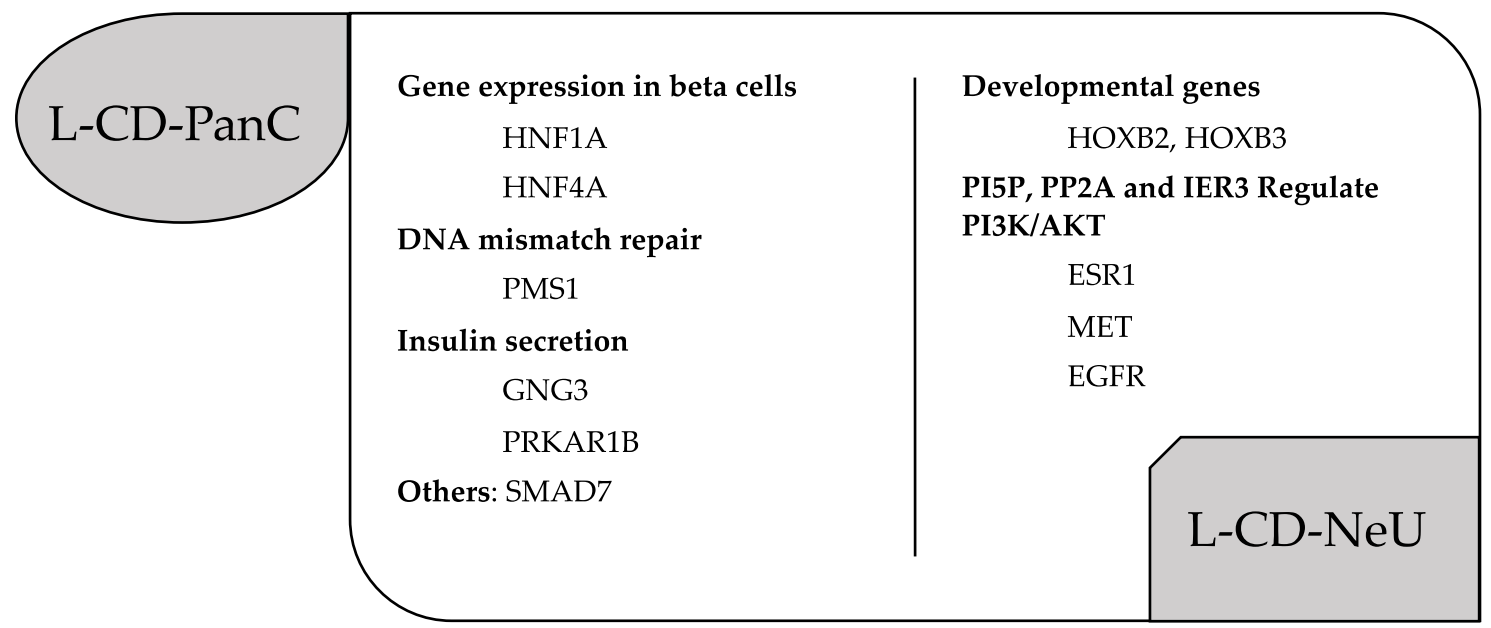

Figure 5: Genes with promoters showing significant differential methylation between L-CD molecular groups. Statistical analysis was performed using a Wald test and $P<1 \times 10^{-6}$ was considered statistically significant. Only DMRs with a methylation difference of $>20 \%$ between the two groups were considered for annotation. 


\section{Tables}

Table 1. The top 20 transcripts differentially expressed between PanC and NeU L-CDs (adj.P<0.01).

\begin{tabular}{|c|c|c|c|c|c|c|}
\hline Gene & $\log _{2} F C(C I)$ & AveExpr & P.Value & adj.P & $\operatorname{PanC}$ & $\mathrm{NeU}$ \\
\hline$A 1 C F$ & $10.63(6.53,14.73)$ & 3.24 & $2.94 \mathrm{E}-13$ & $1.89 \mathrm{E}-09$ & & \\
\hline TM4SF5 & $10.50(10.25,10.73)$ & 1.46 & $2.02 \mathrm{E}-14$ & $3.39 \mathrm{E}-10$ & & \\
\hline SERPINA10 & $9.77(8.37,11.17)$ & 1.12 & $4.39 \mathrm{E}-12$ & $1.03 \mathrm{E}-08$ & & \\
\hline RDH12 & $9.65(8.00,11.30)$ & 4.20 & $8.05 \mathrm{E}-13$ & $3.69 \mathrm{E}-09$ & & \\
\hline RFX6 & $9.42(8.65,10.20)$ & 1.44 & $2.12 \mathrm{E}-13$ & $1.82 \mathrm{E}-09$ & & \\
\hline HNF1A & $8.33(8.04,8.63)$ & 1.16 & $2.63 \mathrm{E}-14$ & $3.39 \mathrm{E}-10$ & & \\
\hline C2orf72 & $7.30(6.79,7.81)$ & 3.41 & $2.02 \mathrm{E}-12$ & 5.79E-09 & & \\
\hline FOXA3 & $7.24(6.91,7.58)$ & 0.60 & $8.18 \mathrm{E}-12$ & $1.76 \mathrm{E}-08$ & & \\
\hline ARHGEF10L & $3.02(2.54,3.51)$ & 6.78 & $1.00 \mathrm{E}-12$ & 3.69E-09 & & \\
\hline GLYCTK & $2.91(2.21,3.62)$ & 4.82 & $1.18 \mathrm{E}-12$ & 3.79E-09 & & \\
\hline RFC3 & $-2.44(-4.40,-0.47)$ & 4.29 & 1.09E-08 & 3.65E-06 & & \\
\hline AUTS2 & $-2.51(-2.91,-2.11)$ & 4.99 & $1.51 \mathrm{E}-08$ & $4.62 \mathrm{E}-06$ & & \\
\hline ATP8A1 & $-2.89(-3.67,-2.11)$ & 5.83 & 3.62E-09 & $1.56 \mathrm{E}-06$ & & \\
\hline DPYSL3 & $-5.08(-6.09,-4.06)$ & 7.31 & $1.10 \mathrm{E}-07$ & $2.08 \mathrm{E}-05$ & & \\
\hline DOK7 & $-5.53(-5.99,-5.07)$ & -1.07 & $1.30 \mathrm{E}-08$ & 4.23E-06 & & \\
\hline PRUNE2 & $-5.58(-6.22,-4.94)$ & 4.63 & 4.71E-08 & $1.18 \mathrm{E}-05$ & & \\
\hline FAM $3 B$ & $-6.21(-7.12,-5.29)$ & 0.98 & $8.76 \mathrm{E}-08$ & $1.76 \mathrm{E}-05$ & & \\
\hline HS3ST6 & $-6.27(-6.71,-5.82)$ & -0.39 & 2.82E-08 & 7.66E-06 & & \\
\hline KCNK10 & $-9.52(-9.86,-9.18)$ & 0.84 & 3.03E-09 & $1.40 \mathrm{E}-06$ & & \\
\hline RALYL & $-9.70(-10.31,-9.08)$ & 0.21 & $1.73 \mathrm{E}-10$ & $1.78 \mathrm{E}-07$ & & \\
\hline
\end{tabular}

Abbreviations: $\log _{2} \mathrm{FC}$ ( $\log _{2}$ fold change); $\mathrm{CI}$ (confidence interval); AveExpr (Average expression across all samples in log2-counts per million); adj.P (Benjamini-Hochberg false discovery rate adjusted $p$-value). Coloured cells indicate relatively higher (red) or lower (blue) gene expression between subtypess. 
medRxiv preprint doi: https://doi.org/10.1101/2021.07.27.21260865; this version posted July 30, 2021. The copyright holder for this preprint (which was not certified by peer review) is the author/funder, who has granted medRxiv a license to display the preprint in perpetuity. It is made available under a CC-BY-NC-ND 4.0 International license.

\section{Methods}

Paired tumour and adjacent normal tissue samples were obtained from 15 patients with a carcinoid diagnosis who had undergone tumour resection at the Royal Brompton Hospital between year 2010 and year 2014. Samples were collected prior to therapy and snap frozen at the time of surgical resection for genomic analyses. For transcriptomics, tissue was stored within two hours in RNAlater. Methods for genomic DNA and RNA extraction have been described previously ${ }^{59}$. Patient consent and tissue banking was carried out under appropriate ethical approval (RBH NIHR BRU Advanced Lung Disease Biobank [NRES reference 10/H0504/9] and Brompton and Harefield NHS Trust Diagnostic Tissue Bank [NRES reference 10/H0504/29]). Tumour diagnosis using the WHO classification and tumour cell abundance were determined through pathology review (AG Nicholson) of haematoxylin and eosin staining. Clinical data is summarised in Supplementary Table 4.

\section{RNA-sequencing (RNA-Seq) and Gene Set Enrichment Analysis (GSEA)}

Total RNA was isolated with the RNEasy Fibrous Midi Kit (Qiagen, Hilden, Germany) from 15 tumour samples. Samples were analysed with the 2100 Bioanalyser and total RNA Nano Kit (Agilent Technologies, California, United States) following manufacturer's instructions. The Illumina TruSeq stranded total RNA Gold sample preparation protocol (RS-122-2301) was used to prepare libraries. RNA sequencing was performed at the Imperial BSC Genomics Facility using the HiSeq4000 system with sequencing by synthesis (SBS) chemistry for paired ends. Raw sequencing reads were quality and adapter trimmed using cutadapt (v.1.9.1) in Trim Galore. Reads were aligned against the December 2013 Human Genome Assembly (GRCh38/ hg38) using STAR (v. 2.7.3a). Processing of the gene count data was performed using voom as implemented in the limma package (v. 3.42.2). Normalised log2-counts per million were used as a measure of gene expression. A heatmap of RNA expression was produced using Euclidean distance across samples with the heatmap.2() function in gplots package (ver. 3.1.1). Clustering validation measures were obtained with clValid R package (ver. 
medRxiv preprint doi: https://doi.org/10.1101/2021.07.27.21260865; this version posted July 30, 2021. The copyright holder for this preprint (which was not certified by peer review) is the author/funder, who has granted medRxiv a license to display the preprint in perpetuity. It is made available under a CC-BY-NC-ND 4.0 International license

0.7). Differential Expression (DE) analysis was modelled using limma (ver. 3.42.2) and the empirical Bayes method. $P$-values were adjusted using a Benjamini Hochberg method to control the FDR below $1 \%$.

The Gene Set Enrichment Analysis (GSEA) (ver. 4.0.3) software was utilised to detect significant group-wise differences in a Reactome Canonical Pathways Gene Set ${ }^{60}$. In the setting of exploratory discovery, we used a less conservative FDR of 0.25 and nominal $P$-value of 0.01 .

\section{WES and mutational analysis}

WES and mutation calling was performed at the McGill Genome Centre, Montreal, Canada. Sequencing libraries were prepared with the SureSelect ${ }^{\mathrm{XT}}$ Target Enrichment System (Agilent SureSelect Human All Exon V4) and sequenced with 100bp Paired-End Illumina HiSeq2000 Sequencer.

Processing and variant calling of the WES data was performed using the analysis piepeline "GenPipes" ${ }^{61}$. In short, Fastq files were trimmed and aligned against the Human Genome December 2013 Assembly (GRCh37/hg19) with BWA mem. SAM files thus obtained per sample were sorted by chromosomic location with GATK (Genome Analysis Tool Kit) (ver.3.7) and read alignments deemed to be PCR duplicates were removed with Picard (ver. 2.9.0). Pre-processing involved local realignment around known insertions/deletions (InDels) and Base Quality Score Recalibration (BQSR) with GATK (ver. 3.7). Somatic mutations and InDels were called with MuTect (ver. 1.16) and Scalpel (ver. 0.4.1) software, respectively. Somatic calls were then combined, and subsequent steps involved decomposing multiallelic variants from VFC files, genetic variant annotation and functional effect prediction with SnpEff (ver. 4.3) and addition of metadata with Genome MINIng (GEMINI) (ver. 0.140.20) software. The annotated variants were filtered based on known impact predictions and CADD scores. We considered pathogenic somatic variants as those with predicted high or medium impact, and those assigned a minimum CADD score of 15 and not flagged as polymorphic. 
medRxiv preprint doi: https://doi.org/10.1101/2021.07.27.21260865; this version posted July 30, 2021. The copyright holder for this preprint (which was not certified by peer review) is the author/funder, who has granted medRxiv a license to display the preprint in perpetuity. It is made available under a CC-BY-NC-ND 4.0 International license .

\section{Identification of Mutational signatures}

The R (ver.3.6.1) DeconstructSigs package (ver. 1.8.0) was used to determine the contribution of known mutational processes in L-CD samples. Signature matrices were calculated based on the fraction of times a mutation was seen in each of the 96-trinucleotide context for each COSMIC catalogued signature (v2). The exome2genome normalisation method was used to reflect the absolute frequency of each nucleotide context as it would across the whole genome. As a result, a reconstructed mutational profile was obtained based on the final weights for each individual sample.

\section{SNP genotyping and identification of Copy Number Alterations (CNAs)}

Illumina Infinium OmniExpressExome (v1.6) arrays were used for genotyping of $>900,000$ SNP markers in 15 tumour and normal matched L-CD samples. The processing and Quality Control were performed with GenomeStudio (ver. 2.0.4). SNPs in pseudo-autosomic regions and InDels were filtered out.

To improve accuracy of copy number variant detection ASCAT (v.2.5.2) was separately applied in tumour and normal samples for GC bias correction. DNACopy (v.1.56.0) was used to segment copy number data into regions of estimated equal copy number. Regions with $>10$ markers support were used for calling CNAs with Gistic2 (ver. 2.0.23). Germline Copy Number Variants (CNVs) were first identified on normal lung tissue samples and were subtracted from the tumour segmented data before CNA calling. Copy number data was visualised using Maftools (ver. 1.9.30).

\section{Whole Genome Bisulfite Sequencing (WGBS-Seq) and Differential Methylation analysis}

WGBS libraries were constructed using the KAPA High Throughput Library Preparation Kit (Roche/KAPA Biosystems) from lug of the sperm DNA spiked with $0.1 \%(w / w)$ unmethylated lambda and pUC19 DNA (Promega). DNA was sonicated (Covaris) and fragments 
medRxiv preprint doi: https://doi.org/10.1101/2021.07.27.21260865; this version posted July 30, 2021. The copyright holder for this preprint (which was not certified by peer review) is the author/funder, who has granted medRxiv a license to display the preprint in perpetuity. It is made available under a CC-BY-NC-ND 4.0 International license.

sizes of 300-400bp were controlled on a Bioanalyzer DNA 1000 Chip (Agilent). Following fragmentation, DNA end repair of double stranded DNA breaks, 3'-end adenylation, adaptor ligation and clean-up steps were conducted according to KAPA Biosystems' protocols. The sample was then bisulfite converted using the Epitect Fast DNA bisulfte kit (Qiagen) following manufacturer's protocol. The resulting bisulfite DNA was quantified with OliGreen (Life Technology) and amplified with 9-12 PCR cycles using the KAPA HiFi HotStart Uracil+ DNA Polymerase (Roche/KAPA Biosystems) according to suggested protocols. The final WGBS libraries were purified using Ampure Beads, validated on Bioanalyzer High Sensitivity DNA Chips (Agilent) and quantified by PicoGreen (ThermoFisher). Sequencing was carried out with the paired-end Illumina HiSeq X Next Generation Sequencing System at the McGill Genome Centre, Montreal, Canada. Analysis of WGBS-Seq data was performed using the Methyl-Seq GenPipes adapted from the Bismark pipeline ${ }^{61}$. Alignment of paired-end reads to bisulfite converted Human Genome (GRCh37/hg19) was performed with bismark (ver. 0.18.1) and bowtie2 (ver. 2.3.1) according to the bismark user guide using the non-directional option. GATK (ver. 3.7) and Picard (ver. 2.9.0) were used to sort by chromosomal location and for the removal of PCR duplicates. The bismark methylation extractor was used to extract methylation in CpG context. Bis-SNP was used to identify SNPs and insertion/deletion events (InDels) that were subsequently filtered out with Bedops (ver. 2.4.35).

Normalisation of the processed WGBS data was carried out with the methylKit $\mathrm{R}$ package (ver. 1.12.0). Finally, Dispersion Shrinkage for Sequencing data with single replicates (DSS-single) implemented in the DSS Bioconductor R package (ver. 2.34.0) was used for calling of Differentially Methylated Regions (DMRs) to account for spatial correlation, read depth and biological variation between groups. Specifically, a smoothing span of 500 bps was used to improve estimation of methylation levels by accounting for nearby CpG sites. A Wald statistical test was then performed for 
medRxiv preprint doi: https://doi.org/10.1101/2021.07.27.21260865; this version posted July 30, 2021. The copyright holder for this preprint (which was not certified by peer review) is the author/funder, who has granted medRxiv a license to display the preprint in perpetuity. It is made available under a CC-BY-NC-ND 4.0 International license .

CpGs with at least 10\% difference between tumour and normal, and the difference was considered significant when $P$-value $<1 \times 10^{-6}$. Regions a minimum of $50 \mathrm{bps}$ in length with at least 3 significant CpGs were identified as DMRs and merged when co-localised by less than 50 bps. Finally, only DMRs with an absolute tumour:normal methylation difference exceeding $20 \%$ were selected for further analysis. DMRs were annotated into different categories with the annotatr R package (ver. 1.12.1). 
medRxiv preprint doi: https://doi.org/10.1101/2021.07.27.21260865; this version posted July 30, 2021. The copyright holder for this preprint

(which was not certified by peer review) is the author/funder, who has granted medRxiv a license to display the preprint in perpetuity. It is made available under a CC-BY-NC-ND 4.0 International license .

\section{$\underline{\text { Acknowledgements }}$}

We thank the patients for participating to our study. We also thank Dr. Alain Pacis and Paul Stretenowich for their help with the analysis of WGBS data. This study was supported by the Asmarley Trust and by the Wellcome Trust. Sample collection for this study was supported by the NIHR Respiratory Disease Biomedical Research Unit at the Royal Brompton and Harefield NHS Foundation Trust. The funding sources had no role in study design, collection, analysis and interpretation of the data, or in the writing of the manuscript.

\section{$\underline{\text { Author contributions }}$}

WOCC and MFM designed and conceptualised the study. EL, AGN and CB recruited patients with histological assessment and meta data provided by CB and AGN. SD performed the RNA sequencing. ML and MM were responsible for the WES and WGBS sequencing with ML directing generation of the data. CDS prepared the SNP genotyping libraries and associated data analysis with input from AN and AM. CD, RE and ML performed the somatic mutation variant calling. CDS performed the somatic InDel calling, DNA methylation and transcriptomic data analysis with input from AM, SWO, JHG and QZ. SP provided critical input on the findings. CDS wrote the manuscript with input from SW-O, WOCC and MFM.

\section{Competing Interests Declaration}

AN reports personal fees from Merck, Boehringer Ingelheim, Novartis, Astra Zeneca, Bristol Myer Squib, Roche, Abbvie and Oncologica, as well as grants and personal fees from Pfizer outside the submitted work. EL reports personal fees from Glaxo Smith Kline, Pfizer, Novartis, Covidien, Roche, Lily Oncology, Boehringer Ingelheim, Medela, Astra Zeneca and Ethicon; grants and personal fees from ScreenCell; grants from Clearbridge Biomedics, Illumina and Guardant Health, outside the 
medRxiv preprint doi: https://doi.org/10.1101/2021.07.27.21260865; this version posted July 30, 2021. The copyright holder for this preprint (which was not certified by peer review) is the author/funder, who has granted medRxiv a license to display the preprint in perpetuity. It is made available under a CC-BY-NC-ND 4.0 International license.

submitted work. In addition, EL has patents P52435GB and P57988GB issued to Imperial Innovations, is the Director of lung screening at the Cromwell Hospital.

\section{Data availability}

Genotyping and sequencing data generated will be submitted at the EGA European GenomePhenome Archive (EGA) (https://ega-archive.org/) under accession code: EGAS00001005473.

\section{Additional Information}

Supplementary Material is available for this paper.

\section{Correspondence}

Correspondence and requests for materials should be addressed to w.cookson@imperial.ac.uk or $\underline{\text { m.moffatt@imperial.ac.uk }}$ 